\title{
The influence of spleen size on the distribution of red cells and plasma
}

\author{
P. J. TOGHILL AND SHEILA GREEN
}

From the General Hospital, Nottingham

SYNOPSIS The red cell mass, splenic red cell pool, and plasma volume have been measured in a series of 64 patients with splenomegaly due to haematological disorders. In 45 patients the total blood volume was increased, this being due to expansion of the plasma volume which was closely correlated with spleen size. There was no significant relationship between the red cell mass and spleen size but the splenic red cell pool increased with increasing spleen size. In 12 patients serial estimations were made whilst changes in spleen size occurred as a result of therapy or progression of the disease. The red cell mass did not alter but the splenic red cell pool showed a significant change from $8.9 \div$ $6.1 \%$ of the red cell mass at minimum spleen size to $17.5 \pm 10.5 \%$ at maximum spleen size. There was progressive expansion of the plasma volume from $42.9 \pm 5.0 \mathrm{ml} / \mathrm{kg}$ at minimum spleen size to $57 \cdot 4 \pm 15 \cdot 3 \mathrm{ml} / \mathrm{kg}$ at maximum spleen size.

In patients with haematological disorders enlargement of the spleen may influence the venous haematocrit level without necessarily acting as a site of haemolysis. Pooling of erythrocytes in the splenic pulp functionally excludes a considerable volume of red cells from the main arteriovenous circulation (Prankerd, 1963) and the effective peripheral venous haematocrit may be further reduced by an apparent increase in the plasma volume (Donaldson, McArthur, MacPherson, and Richmond, 1970). This paper records the blood volumes of 64 patients with splenomegaly due to haematological disorders, and describes serial changes in 12 of these patients in whom there were alterations in spleen size. From these results an attempt is made to define the influence of spleen size on the distribution of red cells and plasma.

\section{Patients and Methods}

Sixty-four Caucasian patients were studied who were admitted to hospital with varying degrees of splenomegaly due to haematological diseases. Patients with cirrhosis and/or portal hypertension were excluded. The causes of the splenomegaly were as follows: lymphoproliferative disorders (including chronic lymphatic leukaemia, lymphosarcoma, and lymphadenoma) in 18 patients; myelosclerosis and myeloid metaplasia in 15 patients; chronic myeloid Received for publication 6 April 1972. leukaemia in 10; autoimmune haemolytic anaemia in three; acute leukaemia in five; a miscellaneous group of 10 patients and three patients who were undiagnosed. In each patient measurements were made of red cell mass, splenic red cell pool, and plasma volume. Twelve patients with splenomegaly were studied serially over a two-year period. From two to five estimations of red cell mass, plasma volume, and splenic red cell pool were carried out on each patient during which time there was a decrease or increase in spleen size of at least $5 \mathrm{~cm}$ below the left costal margin. Splenic size was recorded as the maximum distance of the lower edge downwards and medially from the left costal margin. Those patients in whom the spleen tip was just palpable on deep inspiration were included in this series but shown as having spleens $0 \mathrm{~cm}$ below the left costal margin.

Routine haematological investigations were carried out using standard methods (Dacie and Lewis, 1968). Haematocrit estimations were performed in duplicate with Wintrobe tubes making appropriate allowances for plasma trapping (Chaplin and Mollison, 1952). Erythrocytes were labelled with 30-50 $\mu \mathrm{c}$ sodium chromate $\left(\mathrm{Na}_{2}{ }^{51} \mathrm{CrO}_{4}\right)$ using the method of Joske, McAlister, and Prankerd (1956). After the injection of labelled cells venous samples were taken from the opposite forearm at exactly three and 45 minutes after the midpoint of the injection. After 45 minutes complete equilibration 
of erythrocytes in the splenic pool was assumed and this sample was used to calculate the red cell mass (Toghill, 1965). The three-minute sample was used to estimate the extrasplenic red cell mass and the difference between this figure and the red cell mass was taken to represent the splenic red cell pool.

The plasma volume was measured using ${ }^{131} \mathrm{I}$ labelled human serum albumin, thyroid uptake having been blocked by the administration of oral iodine in the preceding 72 hours. After injection samples of venous blood were taken at exactly five and 10 minutes after the injection. Since clearance of labelled albumin is slow during the first few minutes a zero time activity may be calculated, this being used for the estimation of plasma volume.

\section{Results}

RED CELL MASS AND SPLENIC RED CELL POOLS The red cell mass in this series of patients ranged from $9.8 \mathrm{ml} / \mathrm{kg}$ to $47.0 \mathrm{ml} / \mathrm{kg}$ with a mean of $24.7+$ $8.7 \mathrm{ml} / \mathrm{kg}$ compared with the normal range of 22 to $35 \mathrm{ml} / \mathrm{kg}$. There was no correlation between the red cell mass and spleen size $(r=0.10, P>0.05)$. However, when the venous haematocrit was plotted against spleen size there was a relationship between the falling venous haematocrit with increasing spleen size $(r=-0.36, \mathrm{P}<0.01)$.

The splenic red cell pool, expressed as a percentage of the red cell mass, varied from 0 to $40 \%$ with a mean of $12.3 \pm 10 \cdot 1 \%$. Seven patients had a splenic red cell pool of less than $2.5 \%$ of the red cell mass and of these patients five had spleens less than $3 \mathrm{~cm}$ below the left costal margin. There was a significant correlation between the splenic red cell pool and the splenic size $(r=0.32, \mathrm{P}<0.05)$.

\section{PLASMA VOLUMES}

There was an enormous range in the plasma volumes from 22.5 to $94.0 \mathrm{ml} / \mathrm{kg}$ (mean $52.1 \pm 14.5 \mathrm{ml} / \mathrm{kg}$ ). Most of the plasma volumes were within or above the normal range of 34 to $48 \mathrm{ml} / \mathrm{kg}$, and in all 12 patients with spleens extending to more than $18 \mathrm{~cm}$ below the left costal margin plasma volumes of more than $50 \mathrm{ml} / \mathrm{kg}$ were recorded. There was a highly significant correlation between plasma volume and splenic size $(r=0.62, \mathrm{P}<0.001)$.

\section{TOTAL BLOOD VOLUMES}

The progressive increase in plasma volume was mainly responsible for the high total blood volumes which were related to splenic size $(r=0.51, P<$ 0.001 ). In 45 of the 64 patients the measured blood volume was greater than that predicted from Nadler's formula (Nadler, Hidalgo, and Bloch, 1962). Figure 1 shows the composition of the total

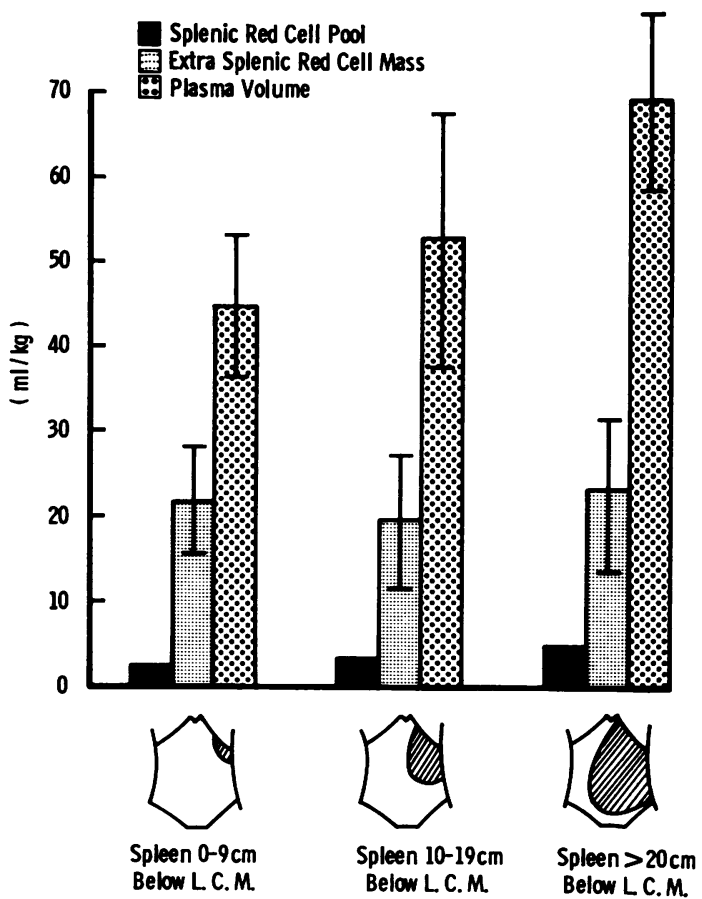

Fig. 1 Components of the total blood volume at various spleen sizes.

blood volumes in three groups of patients with spleens $0-9,10-19$, and over $20 \mathrm{~cm}$ below the left costal margin. Although there was no significant change in the red cell mass, the splenic pool rose from $9.3 \pm 6.5 \%$ of the red cell mass in the group with the smallest spleens, to $15.5 \pm 8.9 \%$ in the intermediate group to $19.1 \pm 6.1 \%$ in patients with the largest spleens.

EFFECTS OF SERIAL CHANGES IN SPLEEN SIZE The clinical details of 12 patients, in whom appreciable changes in spleen size occurred as a result of treatment or progression of the basic disease, are shown in the Table.

The majority of the recordings of red cell mass were within or below the normal range; case 8 with a myeloproliferative syndrome was frankly polycythaemic. There was no appreciable change in the red cell mass with spleen size, the mean level at minimum spleen size being $24.5 \pm 7.7 \mathrm{ml} / \mathrm{kg}$ which was almost identical with the mean level at maximum spleen size $(24.0 \pm 8.3 \mathrm{ml} / \mathrm{kg})$. Although the red cell mass showed no gross change with spleen size in these patients the splenic red cell pool showed a tendency to increase with spleen size. The individual pool sizes showed a wide range from negligible levels 


\begin{tabular}{|c|c|c|c|c|c|c|c|c|}
\hline $\begin{array}{l}\text { Case } \\
\text { No. }\end{array}$ & $\begin{array}{l}\text { Age } \\
(y r)\end{array}$ & Sex & Diagnosis & Treatment & $\begin{array}{l}\text { Spleen Size } \\
(\mathrm{cm}) \text { below Left } \\
\text { Costal Margin }\end{array}$ & $\begin{array}{l}\text { Red Cell Mass } \\
(\mathrm{ml} / \mathrm{kg})\end{array}$ & $\begin{array}{l}\text { Plasma Volume } \\
(\mathrm{ml} / \mathrm{kg})\end{array}$ & $\begin{array}{l}\text { Splenic Pool } \\
(\% \text { of red cell } \\
\text { mass) }\end{array}$ \\
\hline 1 & 45 & $\mathbf{F}$ & Chronic myeloid leukaemia & Busulphan & $\begin{array}{r}9 \cdot 5 \\
24 \cdot 0\end{array}$ & $\begin{array}{l}22 \cdot 3 \\
13 \cdot 4\end{array}$ & $\begin{array}{l}41 \cdot 0 \\
94 \cdot 0\end{array}$ & $\begin{array}{r}5 \cdot 0 \\
16 \cdot 8\end{array}$ \\
\hline 2 & 60 & $\mathbf{F}$ & $\begin{array}{l}\text { Autoimmune haemolytic } \\
\text { anaemia }\end{array}$ & Steroids & $\begin{array}{r}8 \cdot 0 \\
13 \cdot 0\end{array}$ & $\begin{array}{l}29 \cdot 3 \\
35 \cdot 3\end{array}$ & $\begin{array}{l}40 \cdot 6 \\
55 \cdot 0\end{array}$ & $\begin{array}{l}7 \cdot 9 \\
5 \cdot 5\end{array}$ \\
\hline 3 & 32 & $\mathbf{F}$ & Lymphoma & Radiotherapy & $\begin{array}{l}0 \\
9 \cdot 5\end{array}$ & $\begin{array}{l}22 \cdot 0 \\
20 \cdot 0\end{array}$ & $\begin{array}{l}45 \cdot 0 \\
49 \cdot 8\end{array}$ & $\begin{array}{l}3 \cdot 6 \\
9 \cdot 8\end{array}$ \\
\hline 4 & 73 & $\mathbf{F}$ & Lymphoma & Radiotherapy & $\begin{array}{r}6 \cdot 0 \\
22 \cdot 0\end{array}$ & $\begin{array}{l}22 \cdot 3 \\
27 \cdot 0\end{array}$ & $\begin{array}{l}44 \cdot 5 \\
54 \cdot 1\end{array}$ & $\begin{array}{r}8 \cdot 2 \\
12 \cdot 2\end{array}$ \\
\hline 5 & 46 & $\mathbf{F}$ & Chronic myeloid leukaemia & Busulphan & $\begin{array}{l}10 \cdot 0 \\
27 \cdot 0\end{array}$ & $\begin{array}{l}21 \cdot 1 \\
14 \cdot 6\end{array}$ & $\begin{array}{l}47 \cdot 0 \\
v 2 \cdot 4\end{array}$ & $\begin{array}{r}8 \cdot 6 \\
40 \cdot 0\end{array}$ \\
\hline 6 & 62 & $\mathbf{F}$ & Chronic lymphatic leukaemia & Chlorambucil & $\begin{array}{c}0 \\
10 \cdot 0\end{array}$ & $\begin{array}{l}23 \cdot 8 \\
23 \cdot 8\end{array}$ & $\begin{array}{l}42 \cdot 0 \\
37 \cdot 7\end{array}$ & $\begin{array}{l}4 \cdot 2 \\
8 \cdot 1\end{array}$ \\
\hline 7 & 75 & $\mathbf{M}$ & Chronic lymphatic leukaemia & Chlorambucil & $\begin{array}{r}2 \cdot 0 \\
11 \cdot 0\end{array}$ & $\begin{array}{l}26 \cdot 1 \\
20 \cdot 3\end{array}$ & $\begin{array}{l}38 \cdot 5 \\
43 \cdot 4\end{array}$ & $\begin{array}{r}8 \cdot 1 \\
13 \cdot 0\end{array}$ \\
\hline 8 & 61 & $\mathbf{F}$ & Myeloproliferative syndrome & Nil & $\begin{array}{l}12 \cdot 0 \\
28 \cdot 0\end{array}$ & $\begin{array}{l}44 \cdot 8 \\
41 \cdot 3\end{array}$ & $\begin{array}{l}48 \cdot 0 \\
63 \cdot 0\end{array}$ & $\begin{array}{l}18 \cdot 1 \\
15 \cdot 4\end{array}$ \\
\hline 9 & 56 & $\mathbf{F}$ & Lymphoma & Steroids, chlorambucil & $\begin{array}{r}3.0 \\
11.5\end{array}$ & $\begin{array}{l}11 \cdot 0 \\
21 \cdot 0\end{array}$ & $\begin{array}{l}52 \cdot 0 \\
61 \cdot 5\end{array}$ & $\begin{array}{r}0 \\
35\end{array}$ \\
\hline 10 & 47 & $\mathbf{F}$ & Chronic myeloid leukaemia & Busulphan & $\begin{array}{r}5 \cdot 5 \\
13.0\end{array}$ & $\begin{array}{l}22 \cdot 8 \\
31 \cdot 0\end{array}$ & $\begin{array}{l}45 \cdot 0 \\
74 \cdot 0\end{array}$ & $\begin{array}{r}7 \cdot 6 \\
22 \cdot 6\end{array}$ \\
\hline $1 !$ & 65 & $\mathbf{F}$ & Chronic myeloid leukaemia B & Busulphan & $\begin{array}{c}0 \\
10 \cdot 0\end{array}$ & $\begin{array}{l}24 \cdot 7 \\
22 \cdot 7\end{array}$ & $\begin{array}{l}38 \cdot 0 \\
50 \cdot 0\end{array}$ & $\begin{array}{l}15.4 \\
12.6\end{array}$ \\
\hline 12 & 58 & $\mathbf{F}$ & Lymphoma & Cyclophosphamide & $\begin{array}{c}4 \\
12 \cdot 0\end{array}$ & $\begin{array}{l}24.0 \\
18.0\end{array}$ & $\begin{array}{l}33 \cdot 5 \\
44 \cdot 0\end{array}$ & $\begin{array}{l}20 \cdot 3 \\
19 \cdot 6\end{array}$ \\
\hline
\end{tabular}

Table Effect of serial changes in spleen size on the blood volume

up to $40 \%$ of the total red blood cell mass. In eight patients there was an increase in splenic pool size as the spleen itself increased. The mean spleen red cell pool at maximum spleen size was $17 \cdot 5 \pm 10 \cdot 5 \%$

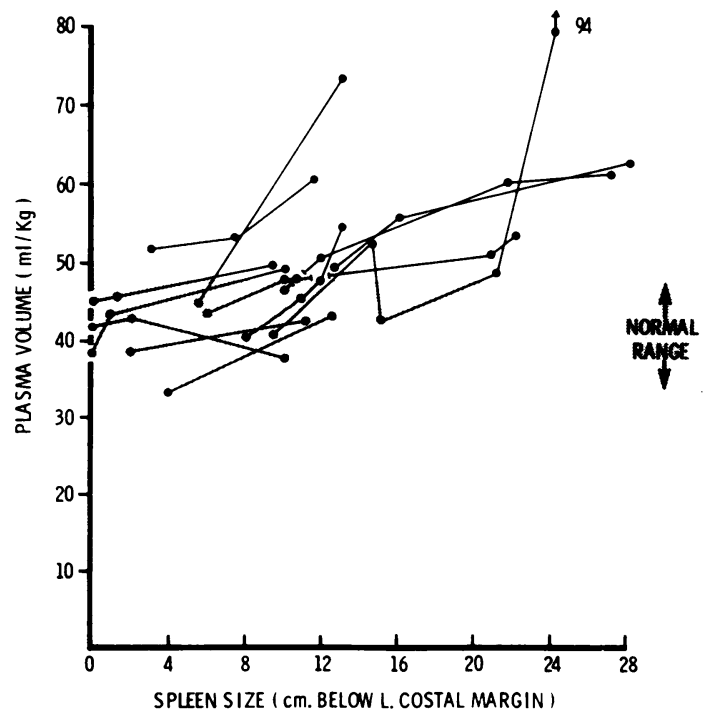

Fig. 2 The serial changes in plasma volume in 12 patients in relation to changes in spleen size. of the red cell mass which was significantly higher than the mean splenic red cell pool at minimum spleen size, which was $8.9 \pm 6.1 \%(\mathrm{P}<0.001)$.

In 11 of the 12 patients there were increases in plasma volume with increasing spleen size (Fig. 2). The remaining patient showed a small increase in plasma volume from 37.7 to $42.0 \mathrm{ml} / \mathrm{kg}$ as the spleen was reduced in size from $10 \mathrm{~cm}$ below the left costal margin to its becoming impalpable. The mean plasma volume at maximum spleen size $(57.4 \pm 15.3 \mathrm{ml} / \mathrm{kg})$ was considerably larger than the mean plasma volume at minimum spleen size $(42.9 \pm 5.0 \mathrm{ml} / \mathrm{kg})$, the difference of these means being highly significant $(\mathrm{P}<0.001)$.

\section{Discussion}

This study confirms the findings of other workers that the total blood volume is increased in patients with splenomegaly, and that this expansion of the blood volume is primarily due to an enlarged plasma volume. The gross increase in plasma volume has now been shown to occur in many haematological disorders (Prankerd, 1963; Weinstein, 1964; Donaldson et $a l, 1970$ ) and also in the various types of tropical splenomegaly as seen in Hong Kong (McFadzean, Todd, and Tsang, 1958), Uganda (Richmond, Donaldson, Williams, Hamilton, and Hutt, 1967), and New Guinea (Pryor, 1967a). The only common factor in this wide spectrum of diseases 
is the gross splenomegaly, and it is now clear that the degree of expansion of the plasma volume is directly proportional to spleen size (Pryor, 1967b; Blendis, Toghill, and Williams, 1969). Increases of 1.5 to $2.5 \%$ in the total blood volume and plasma volume have been predicted for each centimetre increase in the distance of the spleen tip from the costal margin (Bowdler, 1970).

A number of explanations have been put forward to explain the expanded plasma volume in splenomegaly. Bowdler (1970) has pointed out that enlargement of such a vascular organ as the spleen requires an expansion of the blood volume to fill the additional intravascular space. In conditions where the erythropoietic activity of the marrow might be inadequate to maintain the normal red cell/plasma ratio, the additional volume could be provided by plasma expansion. Although hyperglobulinaemia has been suggested as a cause in patients with tropical splenomegaly (Pryor, 1967b) this mechanism cannot be held responsible for other widely differing disorders in temperate zones. Another explanation has been offered by Garnett, Goddard, Markby, and Webber (1969) who have drawn a comparison between the vascular situation in splenic enlargement and the findings with arteriovenous shunts where similar large increases in plasma volume have been recorded. The gross anatomical and haemodynamic differences between large spleens and arteriovenous shunts would seem to make this explanation unlikely.

Although the expansion of the plasma volume seems to be the primary factor responsible for the lowered venous haematocrit level in many patients with splenomegaly, an appreciable proportion of the total red cell mass may be 'pooled' in the spleen in a slowly exchanging second vascular compartment. Most authors have found a direct relationship between the splenic pool size and the degree of splenomegaly (Pryor, 1967b; Donaldson et al, 1970; Christensen, 1971). However, recently Pettit, Williams, Glass, Lewis, Szur, and Wicks (1971) have measured the total blood contained within the spleen utilizing a scanning method with ${ }^{11} \mathrm{C}$ carbon monoxide and were able to show that the total splenic blood was more for a group of patients with myeloproliferative disease than for those with lymphoproliferative disease.

The changes in the blood volumes during treatment are of considerable interest. The gross reduction in plasma volume after splenectomy in the big spleen syndromes has already been frequently recorded (McFadzean, Todd, and Tsang, 1958; Blendis, Clarke, and Williams, 1969) although there is some evidence that the postsplenectomy blood volumes may still be higher than normal (Bowdler, 1970). The observations in this paper indicate that in the vast majority of splenomegalic patients the plasma volume is reduced with shrinkage of spleen size whereas the red cell mass remains constant. It is likely that the rise in haemoglobin level seen in treatment of some of the myelo- or lymphoproliferative disorders could be due to reduction in the spleen size rather than to an improvement in haemopoiesis.

The red cell mass in patients with splenomegaly is a poor index of their clinical condition as a large proportion of the erythrocytes may be held in the spleen and have no influence on the extrasplenic circulation which is additionally diluted by expanded plasma volume. In these cases the packed cell volume may be a more informative measurement. As yet there is no objective evidence that reduction of the plasma volume by surgical or medical splenectomy is beneficial, though a number of authors have commented on the improvement in the clinical state of the patients so treated.

We thank the Sheffield Regional Hospital Board for financial support for the project.

\section{References}

Blendis, L. M., Clarke, M. B., and Williams, R. (1969). Effect of splenectomy on the haemodilutional anaemia of splenomegaly. Lancet, 1, 795-798.

Blendis, L. M., Toghill, P. J., and Williams, R. (1968). Effect of splenomegaly on the plasma volume. In Proceedings of the $3 \mathrm{rd}$ European Congress for the Study of the Liver, Moderna.

Bowdler, A. J. (1970). Blood volume studies in patients with splenomegaly. Transfusion (Philad.), 10, 171-181.

Chaplin, H., Jr., and Mollison, P. L. (1952). Correction for plasma trapped in the red cell column of the hematocrit. Blood, 7, 1227-1238.

Christensen, B. E. (1971). Effects of an enlarged splenic erythrocyce pool in chronic lymphatic leukaemia. Scand. J. Haemat., 8, 92-102.

Dacie, J. V., and Lewis, S. M. (1968). Practical Haematology, 4th ed. Churchill, London.

Donaldson, G. W. K., McArthur, M., MacPherson, A. I. S., and Richmond, J. (1970). Blood volume changes in splenomegaly. Brit. J. Haemat., 18, 45-55.

Garnett, E. S., Goddard, B. A., Markby, D., and Webber, C. E. (1969). The spleen as an arterio-venous shunt. Lancet, 1, 386-388.

Joske, R. A., McAlister, J. M., and Prankerd, T. A. J. (1956). Isotope investigations of red cell production and destruction in chronic renal disease. Clin. Sci., 15, 511-522.

McFadzean, A. J. S., Todd, D., and Tsang, K. C. (1958). Observations on the anemia of cryptogenic splenomegaly: hemolysis. Blood, 13, 513-532.

Nadler, S. B., Hidalgo, J. U., and Bloch, T. (1962). Prediction of blood volume in normal human adults. Surgery, 51, 224-231.

Pettit, J. E., Williams, E. D., Glass, H. I., Lewis, S. M., Szur, L., and Wicks, C. J. (1971). Studies of splenic function in the myeloproliferative disorders and generalized malignant lymphomas. Brit. J. Haemat., 20, 575-586.

Prankerd, T. A. J. (1963). The spleen and anaemia. Brit. med. J., 2, 517-524.

Pryor, D. S. (1967a). Tropical splenomegaly in New Guinea. Quart. J. Med., 36, 321-336.

Pryor, D. S. (1967b). The mechanism of anaemia in tropical splenomegaly. Quart. J. Med., 36, 337-356.

Richmond, J., Donaldson, G. W. K., Williams, R., Hamilton, P. J. S., and Hutt, M. S. R. (1967). Haematological effects of the idiopathic splenomegaly seen in Uganda. Brit. J. Haemat., 13, 348-363.

Toghill, P. J. (1965). Red cell pooling in the spleen. MD Thesis, University of London.

Weinstein, V. F. (1964). Haemodilution anaemia associated with simple splenic hyperplasia. Lancet, 2, 218-223. 